\title{
Teaching Undergraduate Accounting Majors How To Interpret The Accounting Standards Codification: An Alternative To Research Cases
}

Michael C. Toerner, McNeese State University, USA

C. Bruce Swindle, McNeese State University, USA

Daryl V. Burckel, McNeese State University, USA

\begin{abstract}
Professional accountants regularly search the FASB'S Accounting Standards Codification to find answers to financial accounting questions. Accounting educators know this and frequently use research cases in an attempt to help students begin developing this ability. But many students struggle with these cases because they have not been taught how to interpret the Codification and apply its provisions. As a result, research cases often fail to accomplish one of the main purposes for which they are assigned. The authors believe that teaching undergraduate accounting majors how to interpret the Codification is best achieved through an in-class explanation of the process by which the Codification is converted into formulas and journal entries - an approach that they have named the "classroom approach" and that is described in this paper.
\end{abstract}

Keywords: Accounting Education; Intermediate Accounting; Advanced Financial Accounting; Accounting Standards Codification; Research Cases

\section{INTRODUCTION}

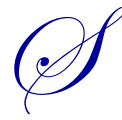

earching the authoritative literature to find the answers to financial accounting questions is something that professional accountants do on a regular basis. But although it is, in a sense, "routine," the research process is not necessarily easy. The difficulty lies not in finding relevant authoritative literature or in writing a report to document the research process and communicate the results thereof. Indeed, practitioners are very familiar with the FASB's Accounting Standards Codification (which constitutes the authoritative literature in the United States and which is referred to hereafter as the "Codification") and have written many such reports. Rather, what makes the research process difficult is having to interpret the Codification.

Consider, for example, the following Codification guidance regarding nonmonetary exchanges and equity method investments.

Paragraph 845-10-30-6 (Nonmonetary Exchanges)

The recipient of the monetary consideration has realized gain . . to the extent that the amount of the monetary receipt exceeds a proportionate share of the recorded amount of the asset surrendered. The portion of the cost applicable to the realized amount shall be based on the ratio of the monetary consideration to the total consideration received (monetary consideration plus the estimated fair value of the nonmonetary asset received) ...

Paragraph 323-10-35-4 (Equity Method Investments)

Under the equity method, an investor shall . . . adjust the carrying amount of an investment for its share of the 
earnings or losses of the investee after the date of investment and shall report the recognized earnings or losses in income.

These paragraphs demonstrate several things about the Codification. First, it is written in a style which is, using the term that Stevens et al. $(1985,91)$ applied to the original documents on which the Codification is based, "foreign" to many readers. As an example, note that the Codification employs the more formal, seldom-used expression "the recipient of the monetary consideration" instead of the less formal, but more understandable, phrase "the entity that receives cash."

Second, rather than use formulas to express mathematical relationships, the Codification describes these relationships in words. Indeed, Paragraph 845-10-30-6 could have communicated the calculation of realized gain more effectively through use of the following formula:

Cash received $-\{$ [cash received $\div$ (cash received + fair value of asset received $)] \mathrm{x}$ book value of asset surrendered $\}$

Third, the Codification excludes journal entries from its discussion of the accounting treatment of an item. In the paragraph dealing with the equity method, for example, the Codification instructs the investor to adjust both its income and the carrying amount of its investment in the investee. A more user-friendly explanation would have been:

The investor's share of the investee's income is recorded by debiting "Investment in (name of investee)" and crediting "Investment Revenue."

One can see, then, why interpreting the Codification is difficult. First, terminology that is rarely used outside of the Codification must be converted into language that is used on a daily basis. Then, once this has been done, the Codification's written descriptions of mathematical relationships and the financial statement effects of accounting transactions must be converted into formulas and journal entries that can be used to develop answers to research questions.

\section{EFFECTIVENESS OF RESEARCH CASES}

Faculty members teaching upper-division accounting courses know that the ability to conduct research is essential in the world of professional accounting and quite understandably want to help their students develop this skill. Consequently, they often assign cases that require students to find relevant authoritative literature, interpret the literature, apply the literature to the facts specified in the case, and communicate the results of that application in a written report.

Cases such as these definitely help students develop their research skills, assuming that the term "research skills" means the ability to navigate one's way through the Codification material and find the number of the Codification topic that relates to the case's subject matter (for example, "Inventory" is Topic 330 and "Equity Method Investments" is Topic 323). Furthermore, because they require a written report of some type, these cases also help students with their communication skills.

But what about students' analytical skills? In other words, their ability to interpret the Codification. How effectively do cases develop these skills?

Ashbaugh and Johnstone (2000) and Duffy and Leinicke (2004) provide direct and indirect answers to these questions. The indirect answer is found in the statement, made by both sets of authors, that student performance improved over the series of cases that they assigned. The unstated implication (which is of particular importance for educators who want to use only one case) seems to be that student performance on the first case was probably not as good as the authors had hoped.

Direct answers to the above questions are found in the authors' descriptions of students' reactions to the cases themselves. Ashbaugh and Johnstone $(2000,76)$ observed that the students in their Intermediate Accounting 
class had "difficulty interpreting" the authoritative literature in a case dealing with accounting for the costs of decommissioning a nuclear power plant. In addition, a second case that asked students to determine if the company in the case had properly accounted for purchased in-process research and development activities "caused problems" for some students $(2000,77)$. Ashbaugh and Johnstone did not identify these problems.

Duffy and Leinicke (2004) used a total of five cases over the course of a two-semester Intermediate Accounting sequence. In each case, students had to identify the research question on their own before they could begin examining the authoritative literature. Not surprisingly, students had a hard time pinpointing the main issues in the cases. This difficulty caused them to experience "frustration," as did "citing as a solution to [a] case ... literature that [was] totally off base" $(2004,146)$. In addition, only 13 of 127 students indicated that "developing the ability to research cases" was an outcome of the case assignments that "will be most valuable to [me] in the future" (2004, 148, Table 3).

\section{AN ALTERNATIVE TO CASES: THE CLASSROOM APPROACH}

In light of the foregoing, the authors believe that research cases, while they have a place in the accounting curriculum, are not the most effective vehicle for helping undergraduate accounting majors develop their analytical skills - that is, their ability to interpret the Codification. In the authors' opinion, this task is accomplished more effectively through an in-class explanation of the process through which the Codification is converted into formulas and journal entries (an approach that is referred to hereafter as the "classroom approach"). The remainder of this section describes the manner in which the authors have used this approach in Intermediate Accounting and Advanced Financial Accounting to teach students how to interpret the Codification.

\section{Mechanics Of The Classroom Approach}

Before undertaking a discussion of the classroom approach, the authors would like to acknowledge the fact that teaching students how to interpret a limited number of Codification paragraphs will not make them experts in interpretation. It will, however, enable them to start building the knowledge structures whose presence is a prerequisite to successfully researching the answers to financial accounting questions.

The classroom approach begins with the identification of topics for which the textbook has provided references to specific Codification paragraphs (see Table 1 for examples taken from two leading Intermediate Accounting textbooks). Using the textbook-supplied references saves time because it eliminates the need to search the Codification on one's own.

From this pool of potential topics, the authors eliminate from further consideration those that deal with financial statement disclosures. This is done because, in the authors' opinion, students can readily comprehend disclosure-related topics.

The topics that remain fall into two categories: those that describe the calculation of some type of amount ("formula" topics) and those that discuss the proper way to account for a transaction ("journal entry" topics). The authors select several topics from each category (the selection is largely a matter of personal preference) and then read the Codification material related to each topic. This material is accessible online by faculty and students through the American Accounting Association for a modest annual fee.

After reading the Codification material, the authors identify the "formula" topics and the "journal entry" topics that will be presented to students in class. This decision is based on an evaluation of the ease with which the Codification material can be incorporated into existing lectures. At a minimum, one "formula" topic and one "journal entry" topic are chosen.

One or two class periods prior to the day on which a "Codification-related" topic is to be discussed, the authors tell students to print the relevant Codification paragraphs (the first day of class involves a 10-15 minute explanation of how to access the Codification) and to bring the printouts to class. On the day on which the topic is discussed, the authors present the Codification material to students as part of that day's lecture. There is, of course, 
no "right" way to do this (instructors have their own unique teaching styles), but the lecture must cover the "key issues" associated with the Codification material. "Key issues" are those that involve the principles and the processes that are used to convert the Codification into formulas and journal entries. Appendix A provides examples of the key issues associated with two Intermediate Accounting topics.

Table 1: Textbook-Supplied Codification References For Intermediate Accounting Topics

\begin{tabular}{|c|c|c|c|}
\hline $\begin{array}{c}\text { Topic } \\
\end{array}$ & Page \# & Footnote \# Or Endnote \# & Codification Reference \\
\hline $\begin{array}{l}\text { Comprehensive income: } \\
\text { Spiceland } \\
\text { Kieso }\end{array}$ & $\begin{array}{l}193 \\
183\end{array}$ & $\begin{array}{l}34 \\
10\end{array}$ & $\begin{array}{c}220-10-45 \\
220\end{array}$ \\
\hline $\begin{array}{l}\text { Nonmonetary exchanges: } \\
\text { Spiceland } \\
\text { Kieso }\end{array}$ & $\begin{array}{l}548 \\
550\end{array}$ & $\begin{array}{c}17 \\
5\end{array}$ & $\begin{array}{c}845 \\
845-10-30\end{array}$ \\
\hline $\begin{array}{l}\text { Interest capitalization: } \\
\text { Spiceland } \\
\text { Kieso } \\
\end{array}$ & $\begin{array}{l}552 \\
542 \\
\end{array}$ & $\begin{array}{c}20 \\
2 \\
\end{array}$ & $\begin{array}{l}835-20-25 \\
835-20-05 \\
\end{array}$ \\
\hline $\begin{array}{l}\text { Asset impairment: } \\
\text { Spiceland } \\
\text { Kieso }\end{array}$ & $\begin{array}{l}614 \\
602\end{array}$ & $\begin{array}{c}15 \\
1\end{array}$ & $\begin{array}{l}360-10-35 \\
360-10-05\end{array}$ \\
\hline $\begin{array}{l}\text { Equity method } \\
\text { investments: } \\
\text { Spiceland } \\
\text { Kieso } \\
\end{array}$ & $\begin{array}{l}681 \\
964\end{array}$ & $\begin{array}{c}31 \\
4\end{array}$ & $\begin{array}{l}323-10-15 \\
323-10-15\end{array}$ \\
\hline $\begin{array}{l}\text { Contingencies: } \\
\text { Spiceland } \\
\text { Kieso }\end{array}$ & $\begin{array}{l}753 \\
715\end{array}$ & $\begin{array}{c}21 \\
8\end{array}$ & $\begin{array}{l}450-20-30 \\
450-10-05\end{array}$ \\
\hline $\begin{array}{l}\text { Convertible debt: } \\
\text { Spiceland } \\
\text { Kieso }\end{array}$ & $\begin{array}{l}823 \\
886\end{array}$ & $\begin{array}{c}15 \\
2\end{array}$ & $\begin{array}{l}470-20-40 \\
470-20-45\end{array}$ \\
\hline $\begin{array}{l}\text { Leases: } \\
\text { Spiceland } \\
\text { Kieso }\end{array}$ & $\begin{array}{c}862 \\
1277\end{array}$ & $\begin{array}{l}3 \\
4 \\
\end{array}$ & $\begin{array}{l}840-10-15 \\
840-10-25\end{array}$ \\
\hline $\begin{array}{l}\text { Income taxes: } \\
\text { Spiceland } \\
\text { Kieso }\end{array}$ & $\begin{array}{c}965 \\
1137\end{array}$ & $\begin{array}{c}15 \\
1\end{array}$ & $\begin{array}{l}740-10-35 \\
740-10-30\end{array}$ \\
\hline $\begin{array}{l}\text { Pensions: } \\
\text { Spiceland } \\
\text { Kieso }\end{array}$ & $\begin{array}{l}1023 \\
1189\end{array}$ & $\begin{array}{c}13 \\
3\end{array}$ & $\begin{array}{l}715-30-25 \\
715-30-25\end{array}$ \\
\hline $\begin{array}{l}\text { Stock dividends: } \\
\text { Spiceland } \\
\text { Kieso }\end{array}$ & $\begin{array}{c}1104 \\
842\end{array}$ & $\begin{array}{c}22 \\
3\end{array}$ & $\begin{array}{c}505-20 \\
505-20-05\end{array}$ \\
\hline $\begin{array}{l}\text { Accounting changes: } \\
\text { Spiceland } \\
\text { Kieso }\end{array}$ & $\begin{array}{l}1210 \\
1344\end{array}$ & $\begin{array}{l}6 \\
1\end{array}$ & $\begin{array}{l}250-10-45 \\
250-10-05\end{array}$ \\
\hline
\end{tabular}

Note 1: "Spiceland" refers to Spiceland et al. (2013) and "Kieso" refers to Kieso et al. (2013).

Note 2: The Spiceland textbook uses footnotes, while the Kieso textbook uses endnotes.

Note 3: Codification references are in a Topic-Subtopic-Section format.

As previously mentioned, the authors' goal in integrating Codification material into classroom lectures is to help students begin forming the knowledge structures that will enable them, as professional accountants, to develop answers to financial accounting questions. The goal is not to measure how well students have mastered the material to which they have been exposed. Consequently, the authors' exams do not include the Codification material that is covered in class (the topic - e.g., equity method investments - is on the exam), nor do they require students to interpret a "similar" Codification paragraph. There is no reason, however, why faculty members who adopt the classroom approach cannot put such questions on their exams if they choose. 


\section{Benefits Of The Classroom Approach}

The authors believe that the classroom approach to teaching students how to interpret the Codification is better than the research-case approach for several reasons. First, the classroom approach is likely to be no more time-consuming than the use of cases, and could quite possibly be less time-consuming. To begin with, the time required to find textbook-supplied Codification references, read the relevant Codification material, identify the key issues in the material, revise topic-specific lectures, and (if so desired) construct Codification-related exam questions is probably the same as the time required to select a case topic, find or prepare background material, identify the research questions, determine the number of points to assign to the case, and provide students with an example of a "good" solution to a similar case. The classroom approach, however, eliminates the need to answer students' questions about the case requirements, which results in better utilization of instructors' in-class and out-of-class time. Furthermore, even if Codification-related questions are included on exams, grading such questions is easier and less time-consuming than grading cases.

Second, students exposed to the classroom approach know that the material being taught will help them in their professional careers and are therefore more highly motivated to learn it. This is not necessarily so with research cases, whose contribution to students' long-term career success is not always obvious. As evidence of this, consider the fact that instructors often assign a "substantial" number of points to research cases in order to encourage students to take the assignments seriously. Also, remember the previously-cited Duffy and Leinicke study - only 10\% of the students in the study felt that the cases on which they had worked would enable them to successfully perform future financial accounting research.

Third, the classroom approach makes the learning process more effective in two ways. The first way relates to the manner in which students use their time outside of class. In order to develop answers to research-case questions, students must use a "teach myself how to interpret the Codification" approach that consumes a significant amount of their out-of-class time. The outcome of this approach is an answer that is very likely to be wrong. Some educators might argue that, despite the incorrect answer, having students try to "self-discover" the answer to a case question is a valuable educational experience. The authors disagree. Students' time outside of class is limited and should be used in as productive a manner as possible. The authors believe that this is accomplished when students study the correct interpretations of Codification material that they are taught under the classroom approach, not when they try to formulate an interpretation that is frequently wrong.

The second way in which the classroom approach makes the learning process more effective is related to the first. As they develop answers to case questions, students subconsciously create knowledge structures that contain the results of their conversion of Codification material into formulas and journal entries. Upon learning from their instructors that their conversions are incorrect, students must dismantle these structures and build new ones. In the authors' opinion, this is a very inefficient use of students' time and mental energy. Under the classroom approach, however, students are able to begin building accurate knowledge structures from the moment that they are exposed to the Codification material.

Finally, the classroom approach is effective in elevating students' confidence in their ability to interpret the Codification on their own. Feedback from student evaluations in an undergraduate, senior-level Advanced Financial Accounting course taught by one of the authors of this paper has shown that, over a series of academic terms, $91 \%$ of the students had more confidence in their ability to interpret the Codification at the end of the terms in which the course was taught than they did at the beginning of the terms.

\section{CONCLUSION}

Neither the classroom approach nor the research-case approach will make students experts in interpreting the Codification. However, for the reasons that have been discussed in this paper, the authors believe that the classroom approach is a more effective way of preparing undergraduate accounting majors to perform this task. 


\section{AUTHOR INFORMATION}

Michael C. Toerner (corresponding author) holds a Ph.D. in Accounting from Louisiana State University and is a licensed CPA. He has eight years of public accounting and industry experience as well as over 30 years of teaching experience. His primary teaching interests are Advanced Financial Accounting and Federal Income Taxation. His main research interests are learning theory, pedagogy, and taxation. E-mail address: miketoerner@gmail.com.

C. Bruce Swindle holds a Ph.D. in Accounting from Louisiana State University and is a licensed CPA. He has substantial consulting experience in addition to 30-plus years of teaching experience. His primary teaching interest is financial accounting at both the undergraduate and graduate levels. His main research interests are financial accounting, international business, accounting education, and workplace-related trust issues. E-mail address: bswindle@mcneese.edu.

Daryl V. Burckel holds a Ph.D. in Accounting from Mississippi State University and is a licensed CPA and a Certified Valuation Analyst. He has extensive public accounting and accounting-education experience. His primary teaching interests are Federal Income Tax, Governmental Accounting, and Accounting Information Systems. His main research interests are financial analysis, business valuation, and taxation. E-mail address: dburckel@mcneese.edu.

\section{REFERENCES}

1. Ashbaugh, H., \& Johnstone, K.M. (2000). Developing students' technical knowledge and professional skills: a sequence of short cases in intermediate financial accounting. Issues in Accounting Education, 15(1), 67-88.

2. Duffy, W.A., \& Leinicke, L.M. (2004). Using the financial accounting research system to develop a professional research competency in intermediate financial accounting. Advances in Accounting Education: Teaching and Curriculum Innovations, 6, 133-154.

3. Kieso, D.E., Weygandt, J.J., \& Warfield, T.D. (2013). Intermediate accounting, $15^{\text {th }}$ edition. Hoboken, NJ: John Wiley \& Sons, Inc.

4. $\quad$ Spiceland, J.D., Sepe, J.F., \& Wilson, M.W. (2013). Intermediate accounting, $7^{\text {th }}$ edition. New York, NY: McGraw-Hill Irwin.

5. Stevens, W.P., Stevens, K.C., \& Raabe, W.A. (1985). FASB statements in the classroom: a study of readability. Advances in Accounting, 2, 89-100. 


\section{APPENDIX A}

\section{Part 1: Key Issues In A Codification Paragraph That Describes A Formula}

Paragraph 845-10-30-6: "The recipient of the monetary consideration has realized gain . . to the extent that the amount of the monetary receipt exceeds a proportionate share of the recorded amount of the asset surrendered. The portion of the cost applicable to the realized amount shall be based on the ratio of the monetary consideration to the total consideration received (monetary consideration plus the estimated fair value of the nonmonetary asset received) ..."

\section{Sentence \#1}

A. This sentence specifies the formula that the recipient of monetary consideration uses to calculate realized gain.

B. "Recipient of the monetary consideration" means the entity that receives cash.

C. "To the extent that" is represented in a formula by the = symbol.

D. "Amount of the monetary receipt" means the amount of cash received.

E. "Exceeds" denotes subtraction and is represented in a formula by a minus sign.

F. Every subtraction problem is of the form: $y=a-b$.

G. As noted in "E," the minus sign in the generic subtraction formula is represented in the Codification paragraph cited above by the word "exceeds." Therefore, "a" in the formula is the term that comes before the word "exceeds," while "b" is the term that comes after the word "exceeds." In light of this fact, "a" is the amount of the monetary receipt and "b" is a proportionate share of the recorded amount of the asset surrendered.

H. At this point, the formula for calculating realized gain is: Realized gain $=$ Cash received - proportionate share of the recorded amount of the asset surrendered

I. "Proportionate share" denotes a proportion or ratio or fraction, which has a numerator and a denominator.

J. The word "of" in the phrase "proportionate share of" is represented in a formula by a multiplication sign.

K. "Recorded amount" means book value or carrying amount.

L. In light of the foregoing, Sentence \# 1 is saying the following: Realized gain $=$ cash received $\{$ [numerator $\div$ denominator] $\mathrm{x}$ book value of asset surrendered $\}$

Sentence \#2

A. This sentence identifies the numerator and the denominator of the fraction that was introduced in Sentence $\# 1$.

B. The use of the word "cost" in the phrase "the portion of the cost" is a poor choice on the part of the Codification writers, who should have used the term "recorded amount" to be consistent with Sentence \#1.

C. The phrase "the portion of the cost applicable to the realized amount" means the portion of the book value of the surrendered asset that is used in the calculation of realized gain.

D. The expression "ratio of . . to ..." designates a fraction. The term that comes after the word "of" and before the word "to" is the numerator. The term that comes after the word "to" is the denominator. Therefore, the monetary consideration (i.e., the cash received) is the numerator. The denominator is the sum (indicated by the word "plus") of the cash received and the fair value of the nonmonetary asset received.

E. In light of "D," the fraction that is used in the calculation of realized gain is: Cash received $\div$ (cash received + fair value of asset received)

\section{Synthesis of Sentences 1 and 2}

A. Combining the analyses of Sentences 1 and 2 yields the following formula for the calculation of realized gain: Cash received $-\{$ [cash received $\div$ (cash received + fair value of asset received) $] \mathrm{x}$ book value of asset surrendered\} 


\section{Part 2: Key Issues In A Codification Paragraph That Describes A Journal Entry}

Paragraph 323-10-35-4: "Under the equity method, an investor shall . . adjust the carrying amount of an investment for its share of the earnings or losses of the investee after the date of investment and shall report the recognized earnings or losses in income."

Analysis

A. This paragraph does not describe the calculation of the investor's "share of the earnings or losses of the investee" nor does it discuss financial statement disclosures. Therefore, it is a "journal entry" paragraph. This conclusion is supported by the presence of the expression "adjust ... and ...," which is indicative of a journal entry.

B. "Its share of the earnings or losses of the investee" is synonymous with "the recognized earnings or losses." Both terms represent the journal entry amount.

C. The item that appears between the word "adjust" and the word "and" is the first item involved in the journal entry. The item that appears after the word "and" is the second item involved in the entry. Thus, the journal entry described in this paragraph involves "the carrying amount of an investment" on the investor's books and the investor's "income."

D. To "report [an item] in income" means to show it on the income statement, which, in turn, means that it will affect the calculation of net income.

E. To see how including the investee's earnings on the investor's income statement will affect the investor's net income, assume that the investor owns $30 \%$ of the investee's stock. Also assume the following:

$\begin{array}{lll}\text { Sales revenue } & \underline{\text { Investor }} & \underline{\text { Investee }} \\ \text { Operating expenses } & \$ 120,000 & \$ 50,000 \\ \text { Net income } & \frac{\$(90,000)}{\$ 30,000} & \frac{\$(40,000)}{\$ 10,000} \\ ====== & =====\end{array}$

F. If the investor included its share of the investee's sales revenue and operating expenses on its income statement (which Paragraph 323-10-35-4 does not require but which will provide insight into what it does require), the investor's net income would be $\$ 33,000$, as shown below.

$\begin{array}{ll}\text { Investor's sales revenue } & \$ 120,000 \\ \text { Investor's share of investee's sales revenue (30\% x \$50,000) } & \$ 15,000 \\ \text { Investor's operating expenses } & \$(90,000) \\ \text { Investor's share of investee's operating expenses }(30 \% \text { x } \$ 40,000) & \$(12,000) \\ \text { Investor's net income } & \$ 33,000 \\ ======\end{array}$

G. As shown in "F," including the investor's share of the investee's sales revenue and operating expenses in the calculation of the investor's net income increases the latter by $\$ 3,000$.

H. In light of "G," the journal entry that the investor must make to record its share of the investee's net income must increase the investor's net income.

I. Net income can be increased by increasing revenues, increasing gains, decreasing expenses, or decreasing losses.

J. Gains and losses typically arise in connection with the sale of assets, the settlement of liabilities, or changes in the value of assets. Expenses are usually associated with the receipt of services from third parties. In light of the fact that Paragraph 323-10-35-4 does not involve any of these events, the investor will increase its net income (as noted in "H") by increasing a revenue account - specifically, "Investment Revenue."

K. Revenue accounts are increased by credits, so the credit in the entry will be "Investment Revenue."

L. As discussed in "C," the journal entry also involves the "carrying amount" of the investor's investment in the investee. The carrying amount is shown on a general ledger page called "Investment in (name of investee)."

M. As indicated in "K," the credit account in the journal entry is "Investment Revenue." Therefore, the debit account has to be "Investment in (name of investee)."

N. If the investee had reported a loss, an analysis process similar to that described above would reveal that the investor would record its share of the loss by debiting "Loss from Investment" and crediting "Investment in (name of investee)." 